\title{
GEOECOLOGICAL PROBLEMS OF FLOW FORMATION IN THE WHITE SEA WATER AREA (ON THE EXAMPLE OF THE KOSTOMUKSHA ORE CLUSTER)
}

\author{
Associate professor, PhD LiudmilaVampilova ${ }^{1}$ \\ Associate professor, PhD Nina Brodskaya ${ }^{2}$ \\ Prof. Dr. Fedor Lisetskii ${ }^{3}$ \\ ${ }^{1}$ Pushkin Leningrad State University, St. Petersburg, Russian Federation \\ ${ }^{2}$ Russian State Hydrometeorological University, St. Petersburg, Russian Federation \\ ${ }^{3}$ Belgorod State National Research University, Federal-regional centre of aerospace and surface \\ monitoring of the objects and natural resources, Belgorod, Russian Federation
}

\begin{abstract}
This work provides justification of the opinion that over the past historic periods natural resource management did not cause serious damage to the environment. The recent epoch differs from the previous ones in a large set of natural resource management types and inter se in the presence of environmental management systems to transform the landscape sphere. In particular, the article examines the mining complex impact on the structure of natural (landscape; hydro-geological; environmental) resources. The purpose of the work was to analyse the role of the anthropogenic factor in the impact of continental runoff and the change in the chemical quality of the sea shelf waters. During deposits development movable rock masses are dumped into disposal areas while refuse ores accumulating in tailings pits. The new landscape conditions to have been emerged impact on natural aquatic ecosystems. This is manifested in decreased water in the quarries of the Kostomuksha ore cluster, in mixed surface and ground water. A change in the hydrodynamic conditions causes the transformation of hydrochemical composition of river and lake ecosystems; increased content of dissolved chemical components; river bed load to enter the western part of the Arctic seawaters of the main drainage area - the White Sea. Thus, there is a geo-technical system being formed, and it goes beyond the scope of land-use management of the mining enterprise as such and involves ecosystems of various hierarchical levels with diverse energy and material flows. As a result, we have identified and characterized a regional geo-ecological problem to have impacted the entire northern and central parts of Karelia in combination with the adjacent seawater areas.
\end{abstract}

Keywords: anthropogenic impact, geo-technical system, mining unit, water and solid runoff, pollution. 


\section{INTRODUCTION}

The eastern part of the Baltic Crystalline Shield within Karelia is a special landscape and historic-geographical region where Karelian, Russian and Saami ethnic groups lived together and historically formed economic and cultural systems typical for taiga landscapes. Before the Slavic ethnos appeared, hunting and fishing prevailed. Historical nature management is a succession of forms of natural resource potential exploitation which is expressed in changing types of nature management and has a specific regional character [1]. Studies of historical nature management can give positive results for the establishment of environmental problems stages. Starting from the $13^{\text {th }}$ century hunting and fishing became to be replaced by hunting and farming colonization. From the 16th to the $17^{\text {th }}$ centuries there were processes in the north of Karelia related with replacement of the indigenous Saami ethnos for local groups and then for the ethnic province of the North Karelians with metallurgic activities being prevailed. The Slavic population on the White Sea is engaged in fishing, hunting for sea animals, salt production and development of shipbuilding and later in agriculture. The scope of timber procurement for heating and maintenance of salt mining and metallurgic industry is significant. From the $18^{\text {th }}$ century deforestation started to gain commercial importance, floating of timber gave rise to anthropogenic transformation of forest and water components. In the $19^{\text {th }}$ century, salt mining was losing its importance, the role of shipbuilding was declining, and timber mills gained the key importance. In the $20^{\text {th }}$ century the nature management system changed to forestry and mining, which was associated with the construction of the railway, the discovery of iron ore deposit and the use of significant potential of forest resources. Since the 1970s a system of hydraulic power facilities (HPPs) has been developing and the Kostomuksha iron ore deposit has been operating.

Belomorskaya Karelia is practically the only "reserved" development area in Karelia. The availability of various types of natural resources (mineral, forestry and energy ones) [2] makes it possible to state that a number of industries can be developed in this region, while a rather low population density supports the establishment of enterprises which could hardly operate in more populated areas for environmental reasons. Thus, the centuries-old history and the intensity of human development of Belomorskaya Karelia landscapes have produced no impact on the state of nature and resources. It is only the nature management system of the 20th century, which caused a series of geo-ecological problems related, first of all, with hydropower construction, creation of transport routes, development of forestry complexes, and, most importantly, mining developments.

\section{METHODS}

The study has applied the hydrochemical testing method for groundwater, surface water and wastewater. A hydrological method has been used to examine the flow rate conditions of the fluviolacustrine system, the levels and the periods for extreme flooding periods, low-water periods and other conditions. Along with the aforementioned, the state of zooplankton and bottom biocenoses of the Kenti-Kento fluviolacustrine system has been comparatively analysed, which made it possible to identify changes in species composition and quantitative indicators of organisms, since zooplankton and benthos respond to mineralized water effects primarily by reducing species diversity. 


\section{RESULTS AND DISCUSSION}

One of the most important factors affecting the hydro-ecological conditions of the White Sea is spatio-temporal variability of river run-off. The western part of the drainage basin is located within the Karelian-Kolsky limnological region and it represents the Belomorskaya subregion (Figure).

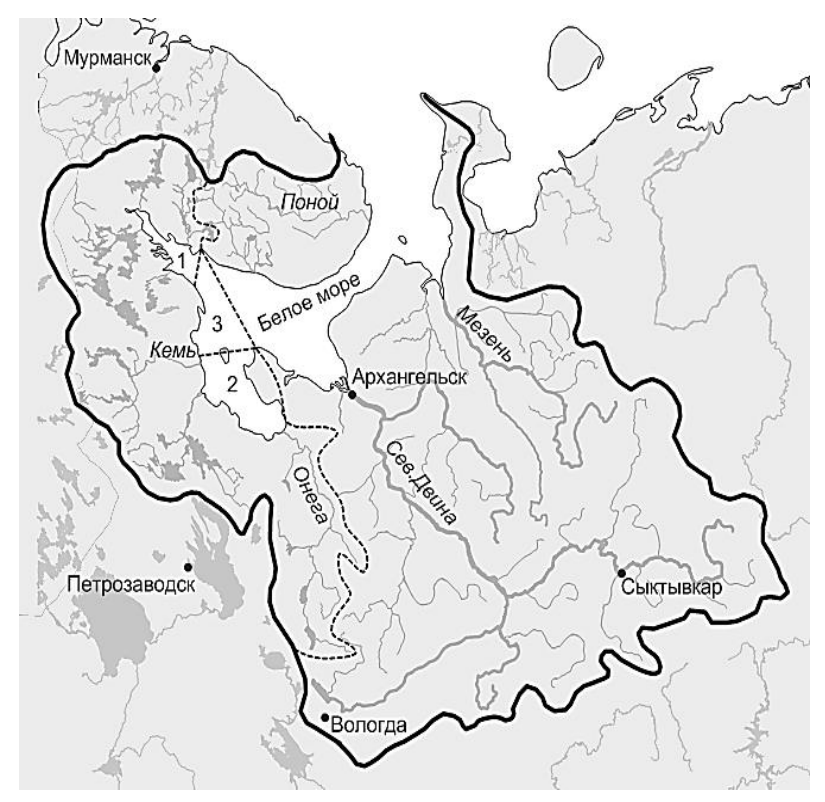

Figure. The White Sea and its catchment: Kandalaksha Bay (1); Onega Bay (2); western part of the basin (3).

The White Sea is characterized by significant differences among specific parts of the water area, which is due to the large length from north to south (over $500 \mathrm{~km}$ ), sea segregation, sea's morphometric features, uneven distribution of river run-off, local climate features, water circulation and anthropogenic factors [3; 4]. The marine environment quality and the marine ecosystems stability depend on a number of anthropogenic factors, which greatly vary in contribution and require ranking for each individual marine basin related with influx of pollutants from river runoff. This type of impact is especially important for the shelf seas of the Arctic Ocean and, in particular, the White Sea in which a large amount of polluted river water enters a relatively isolated sea mass. The catchment area of the White Sea is 720 thousand $\mathrm{km}^{2}$; its length is over 1000 $\mathrm{km}$ from north to south and about $900 \mathrm{~km}$ from west to east. The White Sea basin occupies $59 \%$ of northern and central Karelia. The main characteristics of the river catchments of the White Sea basin are given in Table $1[5 ; 6]$. Under the conditions of increasing technogenic impact on the hydrosphere it is important to study the effect produced by continental runoff on seas, for example, the influence of the Kostomuksha iron ore deposit development on the solid runoff of the western part of the area covered by the White Sea. For more than 50 years, iron ore has been still mined using the blasting method to destroy quartz porphyries followed by excavation and concentration. Rivers flowing into the seas are the main suppliers of chemical components and solid entrained material from the mainland, both natural and anthropogenic origin $[7 ; 8]$. 
Table 1. The catchment areas of the rivers of the White Sea basin and their contribution to the annual runoff.

\begin{tabular}{|c|c|c|c|}
\hline River & Catchment areas, $\mathrm{km}^{2}$ & $\begin{array}{l}\text { Annual runoff at sea, } \\
\mathrm{km}^{3}\end{array}$ & $\begin{array}{l}\text { Share of total sea } \\
\text { runoff, } \%\end{array}$ \\
\hline \multicolumn{4}{|c|}{ The catchment of the western part of the White Sea } \\
\hline Umba & 6250 & 2.47 & 1.09 \\
\hline Niva & 12800 & 5.17 & 2.28 \\
\hline Kovda & 26100 & 8.69 & 3.82 \\
\hline Kem & 27700 & 8.82 & 3.88 \\
\hline Keret & 3660 & 0.94 & 0.41 \\
\hline Kalga & 1590 & 0.32 & 0.14 \\
\hline Wonga & 2580 & 0.69 & 0.30 \\
\hline Shuya & 938 & 0.26 & 0.11 \\
\hline Vyg & 27100 & 8.27 & 3.64 \\
\hline Onega & 56900 & 15.69 & 6.90 \\
\hline Other & 25382 & 7.69 & 3.38 \\
\hline Total & 191000 & 59.01 & 25.97 \\
\hline \multicolumn{4}{|c|}{ The catchment of the eastern part of the White Sea } \\
\hline Northern Dvina & 357000 & 108.15 & 47.59 \\
\hline Mezen & 78000 & 28.00 & 12.32 \\
\hline Ponoy & 15500 & 5.32 & 2.34 \\
\hline Kuloy & 19000 & 6.63 & 2.92 \\
\hline Other & 59500 & 20.14 & 8.86 \\
\hline Total & 529000 & 168.24 & 74.03 \\
\hline
\end{tabular}

An open development of mineral deposits is a powerful man-induced factor to affect natural ecological systems and to form mining systems (MS), thus combining centripetal (consumed natural resources) and centrifugal (products and waste) flows of matter, energy and information [9]. The Kostomuksha mining and processing enterprise is the core or an impact zone, an artificially transformed area, which interacts with indirect influence zone and the external border of the entire hydraulic system, thus shaping the regional specific biological and hydrogeochemical context. The hydrographic network of the Kostomuksha ore cluster (the Koyvas-Kento-Kuito system) belongs to the area covered by the White Sea. The existing small rivers and streams have positive impact on the drainage conditions. There are more than 30 water-sampling stations located within the fluviolacustrine system of the Kenti River (with an area of $949 \mathrm{~km}^{2}$ ). The closest channel lakes of the system are Kostomukshskoye, which was transformed into a tailing 
dump in 1979; Okunievoje, Kurojärvi, Poppalijärvi, Yurikkajärvi, Koivas, Kento et al. $[3 ; 11]$.

The tailing dump wastewater enters the Kenti-Kento fluviolacustrine system by travel of water through a dam and by direct removal of excess water. Until 1994, the tailing dump was operated in a non-discharge mode. Due to the elevation of waterline up to the design level in the tailing dump, water is removed to the fluviolacustrine system in the form of controlled water passes for 10-20 million $\mathrm{m}^{3}$ year $^{-1}[6 ; 8]$. The surface waters of the Kostomuksha River in the estuary contain a large amount of $\mathrm{SO}_{4}, \mathrm{~K}, \mathrm{NH}_{4}, \mathrm{NO}_{3}$ and Biochemical Oxygen Demand (BOD), like groundwater quarry. Given the direction of the underground runoff to the quarries, towards the depression funnel, it should be assumed that the tailing dump affects the conditions of quarry waters (Table 2) [12;13]. The magnetite ores of the deposit contain nickel, zinc, manganese and other compounds as impurity minerals. The content of these elements in banded iron formations is in the range of hundredths to tenths of a percent.

Table 2. Average for 2005-2007 concentration of pollutants in fractions from maximum permissible concentrations in fishery waters (MPCfw) and in fractions from the background $(\mathrm{BG})[6 ; 10 ; 11]$.

\begin{tabular}{|c|c|c|c|c|c|c|c|c|c|}
\hline \multirow{2}{*}{ No } & \multirow[b]{2}{*}{ Indicator } & \multicolumn{2}{|c|}{$\begin{array}{c}\text { Career } \\
\text { drainage } 1\end{array}$} & \multicolumn{2}{|c|}{$\begin{array}{c}\text { Career } \\
\text { drainage } 2\end{array}$} & \multicolumn{2}{|c|}{$\begin{array}{c}\text { Source of Lake } \\
\text { Okunevoe }\end{array}$} & \multicolumn{2}{|c|}{$\begin{array}{c}\text { Tailings } \\
\text { settling pond }\end{array}$} \\
\hline & & $\begin{array}{c}\text { Shares } \\
\text { from } \\
\text { MPCf } \\
\text { w }\end{array}$ & $\begin{array}{c}\text { Share } \\
\text { s } \\
\text { from } \\
\text { BG }\end{array}$ & $\begin{array}{c}\text { Shares } \\
\text { from } \\
\text { MPCf } \\
\text { w }\end{array}$ & $\begin{array}{c}\text { Share } \\
\text { s } \\
\text { from } \\
\text { BG }\end{array}$ & $\begin{array}{c}\text { Shares } \\
\text { from } \\
\text { MPCf } \\
\text { w }\end{array}$ & $\begin{array}{c}\text { Share } \\
\text { s } \\
\text { from } \\
\text { BG }\end{array}$ & $\begin{array}{c}\text { Shares } \\
\text { from } \\
\text { MPCf } \\
\text { w }\end{array}$ & $\begin{array}{c}\text { Share } \\
\text { s } \\
\text { from } \\
\text { BG }\end{array}$ \\
\hline 1 & BOD tot. & 0.31 & - & 0.33 & - & 0.29 & - & 0.4 & - \\
\hline 2 & $\begin{array}{l}\text { Suspende } \\
\text { d matter }\end{array}$ & 0.17 & 0.72 & 0.24 & 1.02 & 0.3 & 1.1 & 0.3 & 1.2 \\
\hline 3 & $\mathrm{~N}-\mathrm{NH}_{4}$ & 2.10 & 13.67 & 0.36 & 2.33 & 1.9 & 12.5 & 0.1 & 0.7 \\
\hline 4 & $\mathrm{~N}-\mathrm{NO}_{2}$ & 2.00 & 20.00 & 0.00 & 0.00 & 2.0 & 20 & 0.5 & 5.0 \\
\hline 5 & $\mathrm{~N}-\mathrm{NO}_{3}$ & 0.17 & 6.20 & 0.09 & 3.20 & 0.3 & 11.8 & 1.0 & 35.8 \\
\hline 6 & $\mathrm{Ca}$ & 0.19 & 17.48 & 0.13 & 11.89 & 0.2 & 17.8 & 0.2 & 16.4 \\
\hline 7 & $\mathrm{Mg}$ & 0.30 & 15.36 & 0.41 & 21.21 & 0.3 & 17.0 & 0.4 & 18.6 \\
\hline 8 & $\mathrm{Na}$ & 0.05 & 8.61 & 0.04 & 6.96 & 0.1 & 12.3 & 0.1 & 25.3 \\
\hline 9 & $\mathrm{~K}$ & 0.74 & 26.31 & 0.45 & 15.98 & 1.2 & 43.1 & 3.6 & 129.5 \\
\hline 10 & $\mathrm{SO}_{4}$ & 1.54 & 64.18 & 1.17 & 48.64 & 1.8 & 76.0 & 2.7 & 110.7 \\
\hline 11 & $\mathrm{Cl}$ & 0.01 & 2.49 & 0.01 & 2.50 & 0.0 & 3.7 & 0.0 & 6.2 \\
\hline 12 & Fe tot. & 6.60 & 2.64 & 7.50 & 3.00 & 5.7 & 2.3 & 1.1 & 0.4 \\
\hline 13 & $\mathrm{Mn}$ & 19.00 & - & 13.00 & - & 20.0 & - & 3.0 & - \\
\hline
\end{tabular}




\begin{tabular}{|l|l|c|c|c|c|c|c|c|c|}
\hline \multirow{2}{*}{\begin{tabular}{l} 
No \\
\multirow{2}{*}{}
\end{tabular}} & \multirow{2}{*}{\begin{tabular}{l} 
Indicator \\
\cline { 3 - 10 }
\end{tabular}} & \multicolumn{2}{|c|}{$\begin{array}{c}\text { Career } \\
\text { drainage 1 }\end{array}$} & \multicolumn{2}{c|}{$\begin{array}{c}\text { Career } \\
\text { drainage 2 }\end{array}$} & \multicolumn{2}{c|}{$\begin{array}{c}\text { Source of Lake } \\
\text { Okunevoe }\end{array}$} & \multicolumn{2}{c|}{$\begin{array}{c}\text { Tailings } \\
\text { settling pond }\end{array}$} \\
\cline { 3 - 10 } & & $\begin{array}{c}\text { Shares } \\
\text { from } \\
\text { MPCf } \\
\text { W }\end{array}$ & $\begin{array}{c}\text { Share } \\
\text { s } \\
\text { from } \\
\text { BG }\end{array}$ & $\begin{array}{c}\text { Shares } \\
\text { from } \\
\text { MPCf } \\
\text { w }\end{array}$ & $\begin{array}{c}\text { Share } \\
\text { s } \\
\text { from } \\
\text { BG }\end{array}$ & $\begin{array}{c}\text { Shares } \\
\text { from } \\
\text { MPCf } \\
\text { W }\end{array}$ & $\begin{array}{c}\text { Share } \\
\text { s } \\
\text { from } \\
\text { BG }\end{array}$ & $\begin{array}{c}\text { Shares } \\
\text { from } \\
\text { MPCf } \\
\text { w }\end{array}$ & $\begin{array}{c}\text { Share } \\
\text { s } \\
\text { from } \\
\text { BG }\end{array}$ \\
\hline 14 & $\mathrm{~F}$ & 0.08 & - & 0.07 & - & 0.1 & - & 0.3 & - \\
\hline 15 & $\mathrm{Li}$ & 0.15 & - & 0.12 & - & 0.4 & - & 1.0 & - \\
\hline 16 & $\mathrm{Ni}$ & 0.38 & - & 0.25 & - & 0.4 & - & 0.7 & - \\
\hline
\end{tabular}

Changes in the hydrochemical regime of the water system because of regular discharge of wastewater from the Kostomuksha tailing dump lead to a gradual change of both chemical water composition and, accordingly, the living environment for aquatic organisms. The rivers of the region serve as sewage receivers $[5 ; 6 ; 10]$. The Kem River receives wastewater from the Yushkozersky integrated timber industry enterprise and household wastewater from the settlement of Kalevala -120 thousand $\mathrm{m}^{3}$, which annually bring 77 tons of dissolved and 76 tons of suspended solids. The Kostomuksha district pollutes the Kento-Kuito fluviolacustrine system by supplying the Kem River with discharge flows of sulphates, nitrogen-ammonium substances and potassium $[11 ; 12]$. The total chemical flow from industrial and public utility facilities of the ecoregion is $53 \%$ of all mineral substances entering the waterways and reservoirs of the republic, including $86 \%$ of sulphates, $50 \%$ of chlorides and $91 \%$ of specific pollutants (organic sulphur compounds and hydrogen sulphide, heavy metals, oil products, phenols , methanol, fluorides, etc.) [12; 13].

\section{CONCLUSION}

The studies conducted in the Kem river basin and, in particular, in the area of the Kostomuksha iron ore deposit have shown that the current landscape and ecological situation has affected the continental runoff conditions and the pollution of the shelf waters in the White Sea environment. To forecast local energy savings, it is promising to use a basin and ecological-regional approach to optimized use of hydrological resources, including the introduction of geographic information and remote sensing technologies $[14 ; 15]$. The results of our analysis based on the examined processes, identified relationships and dependencies will allow us to be most successful in the construction of the following types of models: 1) Electrohydrodynamic analogy (EHDA) models. To reflect adequately the processes of interaction between natural and industrial waters, one can use analogy modelling of GDA type and pollutant dispersion models. For modelling it is essential to create MON (monitoring and observation network) and to generate monitoring observations data; 2) Technical models for factor analysis, classification and systematization of factors with a view to provide an integrated and system approach to the examination of the impact produced by these factors on business results. When using the factor model in practice this will make it possible to minimize the man-made impact on natural water courses during the control of nature management processes. Based on 
these models we can develop control technologies for coastal processes, including the identification of man-made impact zones and their minimization.

\section{ACKNOWLEDGEMENTS}

The work was done in the framework of the implementation of the base part of the state assignment of the Ministry of Education and Science of the Russian Federation for the Belgorod State National Research University on 2020 year (project application No FZWG-2020-0036).

\section{REFERENCES}

[1] Vampilova L.B., Kostovska S.K., Krylova A.N., Lobkovsky V.A., Lobkovskaja L.G., The analysis of the existing techniques of the ecological and geographical assessment of the regions of Russia, 18 International multidisciplinary scientific GeoConference SGEM, Bulgaria, vol. 18/issue 5.2, pp 913-920, 2018.

[2] Sokolova A.A., Vampilova L.B., Brodskaya N.A., Trifonov A.N., Milincic M., Regional educational project geology of the articulation zone of the Baltic shield and sediment cover of the Russian platform, 19 International Multidisciplinary Scientific GeoConference SGEM, Bulgaria, vol. 19/issue 1.1, pp 491-498, 2019.

[3] Bulavina A.S., Features of river runoff formation in the lake-river water collection systems in the western part of the White Sea, Arctic Evironmental Research, vol. 17/issue 3, pp 161-172, 2017. (in Russian).

[4] Bulavina A.S., Zoning of the White Sea catchment area by the degree of continental runoff influence on the marine environment, Vestnik of MSTU, vol. 21/issue 1, pp 117-127, 2018. (in Russian).

[5] Yeshina A.V., Polenov I.K., Bogachev M.A., Terukov V.S., Loginova L.F., Perskaya E.A., Borodulina G.S., Resources and geochemistry of underground waters of Karelia, Petrozavodsk, USSR, 1987. (in Russian).

[6] Monitoring of water bodies in the Kostomuksha region (Kenti, Tollayoki and Korpangiyoki rivers system), Petrozavodsk, Russian Federation, 2007. (in Russian).

[7] Yermolaev O.P., Mukharamova S.S., Maltsev K.A., Ivanov M.A., Ermolaeva P.O., Gayazov A.I., Lisetskii F.N., Geographic information system and geoportal river basins of the European Russia, IOP Conference Series: Earth and Environmental Science, Russian Federation, 2018, 012108.

[8] Kuchko A.A., Sazonov S.S., Kalinkina N.M., Kolomytsev V.A., Kravchenko A.V., Kurkhinen Yu.P., Kuraptseva S.V., Belousova N.A., Andreev K.A., Ecological situation in Karelia, Petrozavodsk, Russian Federation, 1993. (in Russian).

[9] Brodskaya N.A., Vorobiev O.G., Reut O.Ch., Ecological problems of cities, SaintPetersburg, Russian Federation, 1998. (in Russian).

[10] Lozovik P.A., Platonov A.V., Determination of regional maximum permissible concentrations of pollutants using the example of the Karelian hydrographic region, Geoecology, issue 6, pp 527-532, 2005. (in Russian). 
[11] Kalinkina N.M., Kukharev V.I., Morozov A.K., Ryabinkin A.V., Vlasova L.I., Critical levels of mineral pollution of the ecosystem of the river Kenti, Hydrological problems of Karelia and the use of water resources, Petrozavodsk, Russian Federation, 2003, pp 103-110. (in Russian).

[12] Matishov G.G., Dzhenyuk S.L., Bulavina A.S., Integral assessment of the potential impact of continental runoff on the White Sea aquatic environment, Doklady Akademii Nauk, vol. 481/issue 2, pp 203-206, 2018. (in Russian).

[13] Emel'yanova V.P., Lobchenko E.E., Methodical instructions RD 52.24.643-2002 "A method for a comprehensive assessment of the degree of pollution of surface waters by hydrochemical indicators", Moscow, Russian Federation, 2004. (in Russian).

[14] Lisetskii F.N., Zemlyakova A.V., Terekhin E.A., Naroznyaya A.G., Pavlyuk Y.V., Ukrainskii P.A., Kirilenko Zh.A., Marinina O.A., Samofalova O.M., New opportunities of geoplanning in the rural area with the implementing of geoinformational technologies and remote sensing, Advances in Environmental Biology, vol. 8/issue 10, pp 536-539, 2014.

[15] Yermolaev O.P., Lisetskii F.N., Marinina O.A., Buryak Z.A., Basin and ecoregional approach to optimize the use of water and land resources, Biosciences Biotechnology Research Asia, vol. 12, pp 145-158, 2015. 